\title{
PENGARUH PEMAHAMAN KAIDAH PENULISAN SOAL DAN PENGALAMAN MENULIS SOAL TERHADAP KEMAMPUAN MENULIS SOAL BAHASA INDONESIA
}

\author{
Asriani $^{1}$ \\ Abdul Rahman Rahim ${ }^{2}$ \\ Siti Suwadah Rimang ${ }^{3}$ \\ ${ }^{1}$ SDN 222 Inpres Pao-Pao Kecamatan Mandai Kabupaten Maros, Indonesia \\ ${ }^{2,3}$ Universitas Muhammadiyah Makassar, Indonesia \\ ani.morabillu@gmail.com ${ }^{1)}$ \\ rahman@unismuh.ac.id ${ }^{2 *}$ \\ sitisuwadah@yahoo.co.id ${ }^{3)}$
}

\begin{abstract}
Abstrak
Tujuan penelitian ini adalah memperoleh, menganalisis, dan mendeskripsikan data mengenai (1) Pengaruh pemahaman kaidah penulisan soal guru terhadap kemampuan menulis soal bahasa Indonesia guru SDN 222 Inpres Pao-Pao Kecamatan Mandai Kabupaten Maros, (2) Pengaruh pengalaman menuls soal guru terhadap kemampuan menulis soal bahasa Indonesia guru SDN 222 Inpres Pao-Pao Kecamatan Mandai Kabupaten Maros, (3) Pengaruh pemahaman kaidah penulisan soal dan pengalaman menuls soal guru scara bersama-sama terhadap kemampuan menulis soal bahasa Indonesia guru SDN 222 Inpres Pao-Pao Kecamatan Mandai Kabupaten Maros. Jenis penelitian ini adalah penelitian survei dengan teknik korelatif. Adapun populasi penelitian adalah seluruh guru SDN 222 Inpres Pao-Pao Kecamatan Mandai Kabupaten Maros tahun pelajaran 2020/2021. Populasi tersebut berjumlah 18 orang dengan teknik pengambilan sampel adalah total sampling. Hasil penelitian ini menunjukkan bahwa (1) Terdapat pengaruh signifikan antara variabel pemahaman kaidah penulisan terhadap kemampuan menulis soal bahasa Indonesia guru SDN 222 Inpres Pao-Pao Kecamatan Mandai Kabupaten Maros, dengan besar pengaruh $59,70 \%$, (2) erdapat pengaruh signifikan antara variabel pengalaman menulis soal terhadap kemampuan menulis soal bahsa Indonesia guru SDN 222 Inpres Pao-Pao Kecamatan Mandai Kabupaten Maros dengan besar pengaruh 55,29\%. (3) Terdapat pengaruh signifikans secara bersam-sama pemahaman kaidah penulisan soal dan pengalaman menulis soal terhadap kemampuan menulis soal bahsa Indonesia guru SDN 222 Inpres Pao-Pao Kecamatan Mandai Kabupaten Maros dengan besar pengaruh $59,66 \%$.
\end{abstract}

Kata Kunci: Kaidah Penulisan Soal, Pengalaman, Kemampuan Menulis Soal

Published by:

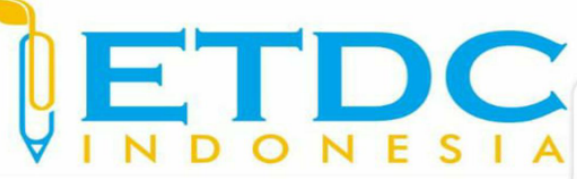

Copyright (C) 2021 The Author (s)

This article is licensed under CC BY 4.0 License

(cc) $\mathrm{BY}$ 


\section{PENGARUH PEMAHAMAN KAIDAH PENULISAN SOAL DAN PENGALAMAN MENULIS SOAL TERHADAP KEMAMPUAN MENULIS SOAL BAHASA INDONESIA}

\section{Pendahuluan}

Penilaian merupakan bagian penting dari perangkat kurikulum. Penilaian dilakukan untuk mengukur dan menilai tingkat pencapaian kompetensi. Penilaian juga digunakan untuk mengetahui kekuatan dan kelemahan dalam proses pembelajaran, fungsi lain penilaian adalah diagnosis dan perbaikan proses pembelajaran. Oleh sebab itu, di samping kurikulum yang baik dan proses pembelajaran yang bermakna diperlukan adanya sistem penilaian yang baik, terencana dan berkesinambungan pada setiap satuan pendidikan. Penilaian terhadap pencapaian kompetensi perlu dilakukan secara objektif berdasarkan kinerja peserta didik dengan bukti penguasaan mereka terhadap pengetahuan, ketrampilan, dan nilai sikap sebagai hasil belajar.

Dalam rangka meningkatkan mutu pendidikan dan mutu sumber daya manusia sesuai dengan standar kompetensi yang ditetapkan secara nasional, maka perlu dilaksanakan sistem penilaian yang baik dan terencana. Sistem penilaian yang baik dan terencana tersebut, tidak lagi dilaksanakan secara terpusat, tetapi diserahkan sepenuhnya kepada sekolah. Ditegaskan di dalam Undang-undang Nomor 20 tahun 2003 tentang Sistem Pendidikan Nasional pasal 58 ayat 1 bahwa dalam rangka pencapaian standar kompetensi siswa, evaluasi hasil belajar siswa dilakukan oleh pendidik untuk memantau proses, kemajuan, dan perbaikan hasil belajar peserta didik secara berkesinambungan. Dengan demikian, pada hakikatnya penilaian terhadap pembelajaran siswa dimulai dan dititikberatkan pada penilaian oleh guru di kelas.

Masalahnya selama ini, masih banyak guru yang kurang terampil dalam membuat tes atau soal. Salah satu penyebanya karena selama ini tidak semua guru dilibatkan dalam pembuatan soal pada masa sebelum otonomi daerah. Soal selalu dibuat terpusat dan guru hanya menggunakan saja. Hal ini mengakibatkan guru kurang terlatih dalam membuat soal pada mata pelajaran yang dijarkan masing-masing. Akibatnya sekarang, soal yang dibuat oleh guru kurang sesuai dengan kriteria soal yang baik atau dengan kata lai tidak kurang berkualitas. Masalah yang biasa dihadapi penulis soal adalah isi soal, konstruk soal, dan bahasa soal masih banyak yang tidak sesuai dengan kriteria penulisan soal.

Hasil pengamatan penulis pada beberapa guru di SDN 222 Inpres Pao-Pao Kecamatan Mandai Kabupaten Maros sekolah, menunjukkan umumnya masih banyak guru sulit menjelaskan kualitas soal yang dibuat, baik bentuk instrumen evaluasi, lembaran evaluasi atau 
butir soal, pedoman penskoran atau rubrik penilaian, dan kunci jawaban, dalam evaluasi proses dan hasil belajar siswa pada mata pelajaran bahasa Indonesia. Sebagian besar guru belum memahami cara menganalisis hasil belajar siswa pada mata pelajaran bahasa Indonesia. Selain itu, masih terdapat berbagai klelemahan, baik berkaitan dengan materi esensial pada kompetensi dasar (KD), pembuatan indicator dalam kisi-kisi soal.

Dengan memahami kondisi yang demikian, maka dipandang perlu adanya upaya untuk meningkatkan kemampuan guru dalam penyusunan soal atau tes hasil belajar termasuk melalui penelitian. Penelitian mengenai penyebab ketidakmampuan guru dalam mendesain peneliaian secara komprehensif, sangat penting dilakukan. Hal ini untuk mencari jalan keluar masalah kemamapuan guru dalam penyusun soal hasil beajar. Oleh karena itu, penulis terdorong melakukan penelitian mengenai kemampuan guru daam menulis soal tes hasil belajar kaitannya dengan pemahaman tentang konsep penulisan tes dan pengalaman guru dalam menulsi soal. Hal ini penting karena ketiga aspek tersebut secara konseptual saling berkaitan. Keterampilan menuli soal membutuhkan pengalaman dan penhgetahuan. Demikian pula pengetahuan bisa melahirkan keterampilan dan keterampilan bisa menimbulkan pegetahuan Tentu saja hal ini harus dibuktikan secara empiris melalui penelitian yang akurat. Penelitian yang dimaksud adalah korelasi tingkat kemampuan menulis soal tes hasil belajar dan pemahaman kaidah menulis serta pengalaman menulis soal bahasa Indonesia guru SDN 222 Inpres Pao-Pao Kecamatan Mandai Kabupaten Maros.

\subsection{Kajian Literatur}

Hakikat kemampuan adalah kesanggupan melakkan sesuatu. Kemampuan adalah suatu kesanggupan dalam melakukan sesuatu. Sesorang dikatakan mampu apabila ia tidak melakukan sesuatu yang harus ia lakukan. Menurut Chaplin dalam bahasa Inggris ability (kemampuan, kecakapan, ketangkasan, bakat, kesanggupan) merupakan tenaga (daya kekuatan) untuk melakukan suatu perbuatan. Sedangkan menurut Robbins kemampuan bisa merupakan kesanggupan bawaan sejak lahir, atau merupakan hasil latihan atau praktik. Adapun menurut Sudrajat (2010) kemampuan adalah menghubungkan kemampuan dengan kata kecakapan. Setiap individu memiliki kecakapan yang berbeda-beda dalam melakukan suatu tindakan. Kecakapan ini mempengaruhi potensi yang ada dalam diri individu tersebut. Proses pembelajaran yang mengharuskan siswa mengoptimalkan segala kecakapan yang dimiliki. (Sriyanto, 2010) Kemampuan juga bisa disebut dengan kompetensi. Kata kompetensi berasal dari bahasa Inggris “competence" yang berarti ability, power, authotity, skill, knowledge, dan kecakapan, kemampuan serta wewenang. Jadi kata kompetensi dari kata competent yang berarti 
memiliki kemampuan dan keterampilan dalam bidangnya, sehingga ia mempunyai kewenangan atau otoritas untuk melakukan sesuatu dalam batas ilmunya tersebut.

Kompetensi merupakan perpaduan dari tiga domain pendidikan yang meliputi ranah pengetahuan, ketrampilan dan sikap yang terbentuk dalam pola berpikir dan bertindak dalam kehidupan sehari-hari. Atas dasar ini, kompetensi dapat berarti pengetahuan, ketrampilan dan kemampuan yang dikuasai oleh seseorang yang telah menjadi bagian dari dirinya sehingga ia dapat melakukan perilaku-perilaku kognitif, afektif dan psikomotorik dengan sebaik-baiknya (Suja, 2015).

\subsection{Kemampuan Menulis Soal}

Menulis ialah menurunkan atau melukiskan lambang-lambang grafik yang menggambarkan suatu bahasa yang dipahami oleh seseorang sehingga orang lain dapat membaca lambang grafik itu. Gambaran atau lukisan mungkin dapat menyampaikan maknamakna, tetapi tidak menggambarkan ketentuan-ketentuan bahasa. Menulis merupakan refresentasi (penulis) dari ketentuan-ketentuan ekspresi bahasa. Hal ini merupakan perbedaan utama antara lukisan dan tulisan (Tarigan, 2015; Natia, 2014). Lain halnya pendapat Gie (2011) mengatakan menulis adalah keseluruhan rangkaian kegiatan seseorang mengungkapkan gagasan dan penyampaian melalui bahasa tulis kepada pembaca untuk dipahami. Norsito (2013); Nur (2011); Rusyana (2011) mengatakan menulis adalah alat yang sangat ampuh dalam belajar yang dengan sendirinya memainkan peran yang sangat penting dalam dunia pendidikan. Kemampuan menulis menghendaki penguasaan berbagai unsur kebahasaan dan unsur di luar bahasa itu sendiri yang akan menjadi isi karangan, baik unsur bahasa maupun unsur isi harus terjalin rapi untuk menghasilkan karangan yang runtut dan padu (Mulyati, 2012). Untuk dapat menyusun suatu tulisan termasuk soal yang baik diperlukan beberapa syarat, antara lain kemampuan berbahasa, pengetahuan struktur bahasa, kemampuan memilih, memahami kaidah penulisan soal, dan menentukan tema tulisan harus banyak membaca dan berlatih.

Banyak orang mencampuradukkan pengertian antara evaluasi, pengukuran, tes, dan penilaian (assessment), padahal keempatnya memiliki pengertian yang berbeda. Evaluasi adalah kegiatan identifikasi untuk melihat apakah suatu program yang telah direncanakan telah tercapai atau belum, berharga atau tidak, dan dapat pula untuk melihat tingkat efisiensi pelaksanaannya. Stufflebeam (Makmun, 1996) memengemukakan bahwa: educational evaluation is the process of delineating, obtaining, and providing useful, information for judging decision alternatif. Pengukuran (measurement) adalah proses pemberian angka atau usaha memperoleh deskripsi numerik dari suatu tingkatan di mana seorang peserta didik telah mencapai karakteristik tertentu. 
Secara khusus, dalam konteks pembelajaran di kelas, penilaian dilakukan untuk mengetahui kemajuan dan hasil belajar peserta didik, mendiagnosa kesulitan belajar, memberikan umpan balik/perbaikan proses belajar mengajar, dan penentuan kenaikan kelas. Melalui penilaian dapat diperoleh informasi yang akurat tentang penyelenggaraan pembelajaran dan keberhasilan belajar peserta didik, guru, serta proses pembelajaran itu sendiri. Definisi lain mengenai tes, Linn \& Gronlund (Sudjana, 2011) mengemukakan bahwa "tes adalah cara penilaian yang dirancang dan dilaksanakan kepada peserta didik pada waktu dan tempat tertentu serta dalam kondisi yang memenuhi syarat-syarat tertentu yang jelas”. Di satu sisi, Mardapi (2014) menambahkan bahwa tes merupakan sejumlah pertanyaan yang memiliki jawaban benar atau salah.

\subsection{Tes Hasil Belajar}

Secara umum sebagaimana dalam petunjuk penilaian (Kemdikbud, 2018) dikemukakan tujuan penilaian hasil belajar (a) menilai pencapaian kompetensi peserta didik; (b) memperbaiki proses pembelajaran; (c) sebagai bahan penyusunan laporan kemajuan belajar siswa. Sejalan dengan hal di atas, Sapari (2017) mengemukakan bahwa tujuan pembelajaran pada hakikatnya adalah perubahan tingkah laku pada diri siswa. Oleh sebab itu dalam penilaian hendaknya diperiksa sejauh mana perubahan tingkah laku siswa telah terjadi melalui proses belajarnya. Dengan mengetahui tercapai tidaknya tujuan pembelajaran, dapat diambil tindakan perbaikan proses pembelajaran dan perbaikan siswa yang bersangkutan. Selain tujuan dan fungsi penilaian, guru juga harus memahami prinsip penilaian. Prinsip penilaian yang dimaksud antara lain sebagaimana dikemukakan oleh (Sudrajad, 2010), yaitu valid/sahih, objektif, transparan/terbuka, adil, terpadu, menyeluruh dan berkesinambungan, bermakna, sistematis, akuntabel, dan beracuan kriteria. Secara umum tes dikenal dalam dua bentuk yaitu tes objektis dan tes uraian atau tes esai.

Beberapa hasil penelitian yang relevan, yaitu Kasiono (2019); Utami \& Nurgiyantoro (2016); Winata (2014), hasil penelitian yang dilakukan secara umum belum melihat kaitan dengan variabel lain dengan tingkat kemampuan menulis soal guru. Sedangkan pada kajian penelitian ini berupaya melihat variable pengalaman belajar dan pemahaman kaidah penulisan soal terhadap kemampan enulsi soal.

Oleh karena itu berdasarkan urain sebelumnya, penulis merumuskan hipotesis yaitu:

1. Apakah terdapat pengaruh signifikan pemahaman kaidah penulisan soal guru terhadap kemampuan menulis soal bahasa Indonesia guru SDN 222 Inpres Pao-Pao Kecamatan Mandai Kabupaten Maros?

2. Apakah terdapat pengaruh signifikan pengalaman menuls soal guru terhadap 
kemampuan menulis soal bahasa Indonesia guru SDN 222 Inpres Pao-Pao Kecamatan Mandai Kabupaten Maros?

3. Apakah terdapat pengaruh signifikan pemahaman kaidah penulisan soal dan pengalaman menuls soal guru secara bersama-sama terhadap kemampuan menulis soal bahasa Indonesia guru SDN 222 Inpres Pao-Pao Kecamatan Mandai Kabupaten Maros?

\section{Metode Penelitian}

Jenis penelitian ini adalah penelitian kuantitatif, deskriptif inferensial. Penelitian penelitian yang berusaha menggambarkan kondisi dan objek penelitian secara apa adanya sebagai pembuktian pengaruh dari variabel dengan variabel lainnya (Sugiyono, 2006). Populasi atau subjek dalam penelitian ini adalah seluruh guru SDN 222 Inpres Pao-Pao Kecamatan Mandai Kabupaten Maros. tahun pelajaran 2020/2021. Populasi tersebut berjumlah 18 orang. Karena jumlah populasi penelitian ini sedikit, maka seluruh populasi dijadikan subjek penelitian (total Sampling). Jadi seluruh populasi menjadi objek penelitian (18 orang). Data dalam penelitian ini dikumpulkan melalui tiga teknik yaitu, teknik tes ( tes pemahaman) untuk mengukur pemahaman konsep kaidah penulisan soal THB guru, teknik nontes (angket) untuk mengukur tingkat pengalaman dalam menulis soal THB ajar guru, dan teknik dokumentasi untuk menilai kemampuan menulis THB bahasa Indonesia yang telah dibuat guru (dokumen soal).

Analisis data menggunakan teknik persentase untuk data tingkat kemampuan menulis soal tes hasil belajar bahsa Indonesia, pemahaman konsep kaidah penulisan soal, dan pengalaman menulis soal bahasa Indonesia guru SDN 222 Inpres Pao-Pao Kecamatan Mandai Kabupaten Maros dengan rumus: n/Nx100 untuk rentang 10-100. Selanjutnya menggunakan teknik statistik inferensial atas rancangan analisis regresi linear berganda. Analisis regresi linear berganda prinsipnya sama dengan analisis regresi linear sederhana, hanya variabel bebasnya lebih dari satu buah. Persamaan umumnya adalah: $Y=a+b_{1} X_{1}+b_{2} X_{2}$. Analisis data menggunakan analisis regresi melalui program Add-Ins Analysis ToolPak of Excel.

\section{Hasil dan Pembahasan}

\subsection{Hasil Penelitian}

Adapun data yang dianalisis adalah hasil tes pemahaman kaidah penulisan soal, hasil angket pengalaman menuls soal, dan kemampuan menulis soal bahasa Indonesia guru SDN 222 Inpres Pao-Pao Kecamatan Mandai Kabupaten Maros. Hasil analisis data tersebut terbagi dalam beberapa jenis, yaitu (1) data tingkat pemahaman kaidah penulisan soal, (2) data tingkat 
pengangalaman menulis soal, (3) data tingkat kemampuan menulis soal tes hasil belajar bahasa Indonesia, (4) data pengaruh pemahaman kaidah penulisan soal terhadap kemampuan menulis soal bahasa Indonesia, (5) data pengaruh pengangalaman menulis soal terhadap kemampuan menulis soal bahasa Indonesia, dan (6) data pengaruh secara bersama-sama pemahaman kaidah penulisan soal dan pengangalaman menulis soal terhadap kemampuan menulis soal bahasa Indonesia guru SDN 222 Inpres Pao-Pao Kecamatan Mandai Kabupaten Maros. Untuk lebih jelasnya diuraikan sebagai berikut.

\section{Tingkat pemahaman kaidah penulisan soal}

Berdasarkan nilai konversi, tingkat pemahaman kaidah penulisan soal guru SDN 222 Inpres Pao-Pao Kecamatan Mandai Kabupaten Maros dapat dilihat pada Tabel berikut.

Tabel 1. Statistik nilai pemahaman kaidah penulisan soal guru

\begin{tabular}{cc}
\hline Statistik & Nilai Statistik \\
\hline Subjek & 18 \\
Nilai Ideal & 100 \\
Nilai Tertinggi & 66,10 \\
Nilai Terendah & 28,81 \\
Nilai Rata-rata & 53,48 \\
\hline
\end{tabular}

Tabel 1 menunjukkan bahwa nilai rata-rata tingkat pemahaman kaidah penulisan soal guru SDN 222 Inpres Pao-Pao Kecamatan Mandai Kabupaten Maros dengan subjek/responden penelitian 18 orang guru sebesar 66,10. Nilai yang dicapai responden tersebar dengan nilai tertinggi 88,33 dan nilai terendah 28,81 dari nilai tertinggi yang mungkin dicapai 100 dan nilai terendah yang mungkin dicapai 0. Selanjutnya nilai tersebut dikaitkan dengan kategorisasi nilai sebagai berikut (LIhat Tabel 2):

Tabel 2. Kategorisasi Nilai

\begin{tabular}{cc}
\hline Nilai & Kategori \\
\hline $0-40$ & Sangat rendah \\
$41-55$ & Rendah \\
$56-70$ & Sedang \\
$71-85$ & Tinggi \\
$86-100$ & Sangat tinggi \\
\hline
\end{tabular}

Berdasarkan Tabel 2 di atas, maka dinyatakan bahwa nilai pemahaman kaidah penulisan soal guru SDN 222 Inpres Pao-Pao Kecamatan Mandai Kabupaten Maros berada pada kategori sedang. 


\section{Tingkat pengalaman menulis soal}

Berdasarkan nilai konversi, tingkat pengalaman menulis soal guru SDN 222 Inpres Pao-Pao Kecamatan Mandai Kabupaten Maros dapat dilihat pada tabel berikut.

Tabel 3. Statistik nilai pemahaman kaidah penulisan soal guru

\begin{tabular}{lc}
\hline \multicolumn{1}{c}{ Statistik } & Nilai Statistik \\
\hline Subjek & 18 \\
Nilai Ideal & 100 \\
Nilai Tertinggi & 85,71 \\
Nilai Terendah & 50,00 \\
Nilai Rata-rata & 62,30 \\
\hline
\end{tabular}

Tabel 3 menunjukkan bahwa nilai rata-rata tingkat pengalaman menulis soal guru SDN 222 Inpres Pao-Pao Kecamatan Mandai Kabupaten Maros dengan subjek/responden penelitian 18 orang guru sebesar 62,30. Nilai yang dicapai responden tersebar dengan nilai tertinggi 85,71 dan nilai terendah 50,00 dari nilai tertinggi yang mungkin dicapai 100 dan nilai terendah yang mungkin dicapai 0. Selanjutnya nilai tersebut dikaitkan dengan kategorisasi nilai. Berdasarkan kategorisasi di atas, maka dinyatakan bahwa nilai pengalaman menulis soal guru SDN 222 Inpres Pao-Pao Kecamatan Mandai Kabupaten Maros berada pada kategori sedang.

\section{Tingkat kemampuan menulis soal bahasa Indonesia}

Berdasarkan nilai konversi, tingkat kemampuan menulis soal bahasa Indonesia guru SDN 222 Inpres Pao-Pao Kecamatan Mandai Kabupaten Maros dapat dilihat pada Tabel 4 berikut.

Tabel 4. Statistik nilai kemampuan menulis soal guru

\begin{tabular}{cc}
\hline Statistik & Nilai Statistik \\
\hline Subjek & 18 \\
Nilai Konversi Ideal & 100 \\
Nilai Tertinggi & 85,71 \\
Nilai Terendah & 50,00 \\
Nilai Rata-rata & 62,30 \\
\hline
\end{tabular}

Tabel 4 menunjukkan bahwa nilai rata-rata tingkat pengalaman menulis soal guru SDN 222 Inpres Pao-Pao Kecamatan Mandai Kabupaten Maros dengan subjek/responden penelitian 18 orang guru sebesar 63,33. Nilai yang dicapai responden tersebar dengan nilai tertinggi 69,57 dan nilai terendah 53,91 dari nilai tertinggi yang mungkin dicapai 100 dan nilai terendah yang mungkin dicapai 0. Selanjutnya nilai tersebut dikaitkan dengan kategorisasi nilai. Berdasarkan kategorisasi di atas, maka dinyatakan bahwa nilai kemampuan menulis soal bahasa Indenesia guru SDN 222 
Inpres Pao-Pao Kecamatan Mandai Kabupaten Maros berada pada kategori sedang.

\section{Pengujian Hipotesis (variabel X1 terhadap Y)}

Untuk menentukan ada-tidaknya pengaruh antara variabel X1 terhadap Y (pemahaman kaidah penulisan soal terhadap kemampaun menulis soal bahasa indonesia), maka data dari kedua variabel dianalisis dengan menggunakan komputer program $\underline{A d d-I n s}$ Analysis ToolPak of Excel. Adapun hasil analisis regresi variabel dikemukakan ringkasan hasil analisis data sebagai berikut (Lihat Tabel 5).

Tabel 5. Hasil Analisis Regresi variabel X1 dan X2

\begin{tabular}{lcccc}
\hline & Coefficients & Standard Error & t Stat & P-value \\
\hline Intercept & 2,882362 & 1,222439 & 2,357878 & 0,031442 \\
Pemahman Kaidah & 0,185066 & 0,038014 & 4,868363 & 0,000171 \\
Penulisan Soal (X1) & & & \\
\hline
\end{tabular}

Dari Tabel 5 di atas dikemukakan:

alpha $\quad:(0,05)$

P-value $\quad: 0,031442$

Kriteria uji : Ho ditolak jika jika P-value $<$ alpha $(0,05)$

Keputusan : Ho ditolak jika karena P-value $(0,031442)<$ alpha $(0,05)$

Kesimpulan : terdapat pengaruh signifikan antara variabel pemahaman kaidah penulisan terhadap kemampuan menulis soal bahsa Indonesia guru SDN 222 Inpres Pao-Pao Kecamatan Mandai Kabupaten Maros.

Berdasarkan hasil ringkasan koofisien determinasi di atas dapat diperoleh nilai R-Square: 0,596987 yang artinya bahwa variabel pemahaman kaidah penulisan mempengaruhi kemampuan menulis soal bahasa Indonesia 59,70\%, sisanya dipengaruhi oleh variabel lain yang tidak dibahas.

\section{Pengujian Hipotesis (variabel $\mathrm{X} 2$ terhadap $Y$}

Untuk menentukan ada-tidaknya pengaruh antara variabel $\mathrm{X} 2$ terhadap $\mathrm{Y}$ (pengalaman menulis soal terhadap kemampaun menulis soal bahasa indonesia), maka data dari kedua variabel dianalisis dengan menggunakan komputer program $\underline{A d d-I n s}$ Analysis ToolPak of Excel. Adapun hasil analisis regresi kedua variabel dikemukakan ringkasan hasil analisis data sebagai berikut (Lihat Tabel 6).

Tabel 6. Hasil Analisis Regresi variabel X2 dan Y

\begin{tabular}{lcccc}
\hline & Coefficients & Standard Error & t Stat & P-value \\
\hline Intercept & $-5,49792$ & 3,206673 & $-1,71452$ & 0,027333 \\
\hline
\end{tabular}




\begin{tabular}{lcccc}
\hline & Coefficients & Standard Error & t Stat & P-value \\
\hline $\begin{array}{l}\text { Pengalaman Menulis } \\
(\mathrm{X} 2)\end{array}$ & 0,195242 & 0,043896 & 4,447868 & 0,000405 \\
\hline
\end{tabular}

Dari Tabel 6 di atas dikemukakan:

Hipotesis:

alpha $\quad:(0,05)$

P-value $\quad: 0,027333$

Kriteria uji : Ho ditolak jika jika P-value $<$ alpha $(0,05)$

Keputusan : Ho ditolak jika karena P-value $(0,027333)<$ alpha $(0,05)$

Kesimpulan : terdapat pengaruh signifikan antara variabel pengalaman menulis soal terhadap kemampuan menulis soal bahsa Indonesia guru SDN 222 Inpres Pao-Pao Kecamatan Mandai Kabupaten Maros.

Berdasarkan hasil ringkasan koofisien determinasi di atas dapat diperoleh nilai $R$ Square: 0,552867 yang artinya bahwa variabel pengalaman menulis soal mempengaruhi kemampuan menulis soal bahasa Indonesia 55,29\%, sisanya dipengaruhi oleh variabel lain yang tidak dibahas.

\section{Pengujian Hipotesis (variabel X1 dan X2 terhadap $Y$ )}

Adapun ringkasan hasil analisis regresi pengaruh variabel kemampuan memahami kaidah penulisan soal dan pengalaman menulis soal secara bersama-sama/simultan terhadap kemampuan menulisn soal bahasa Indonesia sebagai berikut (Lihat Tabel 7).

Tabel 7. Hasil Analisis Regresi variabel X1 dan X2 terhadap Y

\begin{tabular}{lcccc}
\hline & Coefficients & Standard Error & t Stat & P-value \\
\hline Intercept & $-1,77525$ & 3,512125 & $-0,50546$ & 0,020579 \\
$\begin{array}{l}\text { Pemahaman } \quad \text { dan } \\
\text { pengalaman (X1 dan X2) }\end{array}$ & 0,118041 & 0,060201 & 1,960793 & 0,068744 \\
\hline
\end{tabular}

Dari Tabel 7 di atas dikemukakan:

Hipotesis:

alpha $\quad:(0,05)$

P-value $\quad: 0,020579$

Kriteria uji : Ho ditolak jika jika $\mathrm{P}$-value $<$ alpha $(0,05)$

Keputusan : Ho ditolak jika karena P-value $(0,020579)<$ alpha $(0,05)$

Kesimpulan : Terdapat pengaruh signifikans secara bersam-sama pemahaman kaidah penulisan soal dan pengalaman menulis soal terhadap kemampuan menulis 
soal bahsa Indonesia guru SDN 222 Inpres Pao-Pao Kecamatan Mandai Kabupaten Maros.

Berdasarkan hasil rinmgkasan koofisien determinasi di atas dapat diperoleh nilai Adjusted R Square: 0,596637 yang artinya bahwa secara bersama-sama varaibel X1 (pemahaman kaidah penulisan soal) dan variabel X2 (pengalaman menulis soal) mempengaruhi kemampuan menulis soal bahasa Indonesai 59,66\%, sisanya dipengaruhi oleh variabel lain yang tidak dibahas.

\subsection{Pembahasan}

Berdasarkan hasil analisis data, maka dapat diketahui bahwa pada analisis data tingkat pemahaman kaidah penulisan soal guru SDN 222 Inpres Pao-Pao Kecamatan Mandai Kabupaten Maros, nilai rata-rata sebesar 66,10, nilai tertinggi 88,33 dan nilai terendah 28,81, dan berada pada kategori sedang. Analisis data tingkat pengalaman menulis soal guru SDN 222 Inpres Pao-Pao Kecamatan Mandai Kabupaten Maros, nilai rata-rata sebesar 62,30, nilai tertinggi 85,71 dan nilai terendah 50,00 dan berada pada kategori sedang. Analisis data tingkat kemampuan menulis soal bahasa Indonesia guru SDN 222 Inpres Pao-Pao Kecamatan Mandai Kabupaten Maros, nilai rata-rata sebesar 63,33, nilai tertinggi 67,57 dan nilai terendah 53,91 dan berada pada kategori sedang.

Selanjutnya, berdasarkan pengujian hipotesis menunjukkan bahwa (1) terdapat pengaruh signifikan antara variabel pemahaman kaidah penulisan terhadap kemampuan menulis soal bahsa Indonesia guru SDN 222 Inpres Pao-Pao Kecamatan Mandai Kabupaten Maros, dengan besar pengaruh 59,70\%, (2) terdapat pengaruh signifikan antara variabel pengalaman menulis soal terhadap kemampuan menulis soal bahsa Indonesia guru SDN 222 Inpres Pao-Pao Kecamatan Mandai Kabupaten Maros dengan besar pengaruh 55,29\%. (3) terdapat pengaruh signifikans secara bersam-sama pemahaman kaidah penulisan soal dan pengalaman menulis soal terhadap kemampuan menulis soal bahasa Indonesia guru SDN 222 Inpres Pao-Pao Kecamatan Mandai Kabupaten Maros dengan besar pengaruh 59,66\%.

Uraian di atas menunjukkan bahwa guru yang memiliki pemahaman kaidah penulisan berpengaruh terhadap tingginya kemampuan menulis soal bahasa Indonesia. Demikian halnya guru yang memiliki pengalaman tinggi juga memiliki kemampuan menulis soal yang tinggi. Hasil penelitian ini sesuai dengan pandangan Agung (2013) menyatakan bahwa faktor yang mempengaruhi kemapuan menulis soal seseorang guru adalah minat, pemahaman tentang konsep soal dan latihan dalam menulis soal. Selain itu, faktor kebiasaan atau pengalaman yang dimiliki. Semakin terbiasa menulis soal maka kemampuan dan kualitas soal yang dibuat guru 
akan semakin baik. Selain itu, Yudiona (2014) menyatakan bahwa salah satu syarat penting sesorang dalam menulis soal adalah memahami cara menulis soal yang baik. Akan tetapi memahami cara menuls soal yang baik saja, belum tentu dapat menulis soal yang baik, tetapi perlu latihan yang berulang-ulang.

Hal di atas menguatkan konsep mengenai pentingnya teori yang dikemukakan oleh Nasita (2011) bahwa, teori sangat penting bagi sustu yang akan dikerjakan secara profesional. Tanpa teori, praktik hanya didasarkan atas alasan-alasan yang kebetulan. Sementara, masalah menulis soal bukanlah suatu hal yang sekadar dieksperimen pembentukannya, tetapi disandarkan pada pada konsep yang ada sebagai suatu norma kebenarannya. Oleh karena itu, teori dan praktik haruslah seimbang, karena teori merupakan pedoman untuk memudahkan berjalannya praktik.

\section{Kesimpulan}

Berdasarkan rumusan masalah dan hipotesis penelitian yang diajukan, serta hasil penelitian yang didasarkan pada analisis data dan pengujian hipotesis maka dapat disimpulkan bahwa:

a. Terdapat pengaruh signifikan antara variable pemahaman kaidah penulisan terhadap kemampuan menulis soal bahsa Indonesia guru SDN 222 Inpres Pao-Pao Kecamatan Mandai Kabupaten Maros, dengan besar pengaruh 59,70\%,

b. Terdapat pengaruh signifikan antara variabel pengalaman menulis soal terhadap kemampuan menulis soal bahsa Indonesia guru SDN 222 Inpres Pao-Pao Kecamatan Mandai Kabupaten Maros dengan besar pengaruh 55,29\%.

c. Terdapat pengaruh signifikans secara bersam-sama pemahaman kaidah penulisan soal dan pengalaman menulis soal terhadap kemampuan menulis soal bahsa Indonesia guru SDN 222 Inpres Pao-Pao Kecamatan Mandai Kabupaten Maros dengan besar pengaruh $59,66 \%$.

\section{DAFTAR PUSTAKA}

Absari, I. G. A. K. L., Sudiana, I. N., \& Wendra, I. W. (2015). Penilaian autentik guru bahasa Indonesia dalam pembelajaran menulis siswa kelas VII di SMP Negeri 1 Singaraja. Jurnal Pendidikan Bahasa dan Sastra Indonesia Undiksha, 3(1).

Agung, M. (2013). Mengembangkan Soal Tes Hasil Belajar. Jakarta: Insan Press

Azwar, S. (2014). Penilaian Pembelajaran, Sebuah Pengantar. Jogjakarta: Analisa 
Gie, L. (2011). Terampil Mengarang. Edisi I. Yogyakarta.

Hasibuan, E. S. B. (2013). Analisis Soal Ulangan Tengah Semester Bahasa Indonesia Kelas Xii Mas Raudhatul Ulum Meranti. Jurnal Pendidikan dan Pembelajaran Khatulistiwa, 2(4).

Kasiono, D. (2019). Peningkatan Kemampuan Menyusun Soal dengan Metode Pendampingan Berpola SP3R pada Guru SDN Sepanyul Kecamatan Gudo Kabupaten Jombang Tahun 2018. JDMP (Jurnal Dinamika Manajemen Pendidikan), 4(1), 33-41.

Kadarwati, A. (2017). Peningkatan Kompetensi Calon Pendidik SD Dalam Pengembangan Tes Hasil Belajar. Premiere Educandum: Jurnal Pendidikan Dasar dan Pembelajaran, 7(01), 76-86.

Kemdikbud. (2018). Pedoman Penilaian Sekolah Dasar. Jakarta: Dikdasmen

Makmun, S. (1996). Penilain Kelas. Jakarta: Multi Aksara

Marimin, M. (2017). Upaya Meningkatkan Kemampuan Guru Dalam Menyusun Tes Hasil Belajar Akhir Semester I Melalui Supervisi Akademik Pada Kelas V Dabin Ii Pattimura Kecamatan Jatiyoso Tahun Pelajaran 2016/2017. JURNAL MITRA SWARA GANESHA, $4(1)$.

Mardapi, D. (2014). Penilaian Otentik. Bahan Pelatihan pada Konferensi HEPI.

Mulyati. (2012). Keterampilan Menulis. Bandung: Remaja Rosdakarya.

Munadi, S. (2011). Analisis validasi kualitas soal tes hasil belajar pada pelaksanaan program pembelajaran. Jurnal Cakrawala Pendidikan, 1(1).

Nasita, H. (2011). Bekerja Profesional. Bandung: Angkasa

Natia, A. (2014). Memupuk keterampilan Menulis. Jakarta: Gema Press

Ningsih, J. W. (2010). Kesalahan penggunaan bahasa Indonesia dalam soal ulangan umum akhir semester i dan ii pada siswa kelas vi sekolah dasar di wilayah kecamatan Nguter kabupaten Sukoharjo tahun ajaran 2008/2009.

Nur, M. (2011). Pembelajaran Terpadu di Sekolah Dasar. Jakarta: Gema Press

Nursito. (2013). Penuntun Mengarang. Yokyakarta : Adicita Karya Nusa.

Peraturan Menteri Pendidikan Nasional Republik Indonesia Nomor 41 Tahun 2007 tentang Standar Proses untuk Satuan Pendidikan Dasar dan Menengah.

Peraturan Pemerintah Nomor 19 Tahun 2005 tentang Standar Nasional Pendidikan.

PINEM, Y. E. B. (2021). Analisis Kesulitan Kepemahaman Siswa Dalam Menulis Berita Singkat Pada Pelajaran Bahasa Indonesia Kelas Iv Sd Negeri 067246 Medan Tahun Pelajaran 2020/2021 (Doctoral dissertation, UNIVERSITAS QUALITY). 
Rusyana, Y. (2011). Menulis sebagai Sebuah Keterampilan. Jakarta: Gema Media

Sapari, A. (2017). Penilaian Pendidikan. Yogyakarta: Analisis

Sidiqin, M. A., \& Siregar, S. (2020). Pengaruh Media Audio Visual Terhadap Kemampuan Menulis Teks Eksposisi Siswa Kelas X Smk Satria Nusantara Binjai Tahun Pelajaran 2019/2020. Jurnal Serunai Bahasa Indonesia, 17(1), 35-41.

Sholichah, D. N., \& Hariani, S. (2020). Pengembangan media popscrap book untuk pembelajaran menulis teks eksposisi di Kelas V Sekolah Dasar.

Sriyanto, D. (2010). Menuju Profesionalisme Guru. Jakrta: Askarfress

Sudjana, N. (2011). Penilaian hasil dan proses belajar mengajar. Bandung: rosda karya, 180.

Sudrajat, A. (2010). Mengoptimalkan Potensi Diri. Jakarta: Gema Mwdia

Sugiono. (2018). Metode Penelitian Kuantitatif, Kualitatif, dan R\&D. Bandung. Alfabeta.

Suja, A. (2015). Psikologi Perkembangan. Jakarta: Gema Aksara

Tarigan, M. R. (2015). Peningkatan Keterampilan Menulis Paragraf Eksposisi Melalui Metode Diskusi dengan Media Koran Siswa Kelas X SMA Negeri 6 Binjai Tahun Pelajaran 2013/2014. Jurnal Edukasi Kultura: Jurnal Bahasa, Sastra dan Budaya, 2(2).

Tarigan, J. (2018). PENERAPAN MODEL PEMBELAJARAN BERBASIS MASALAH DENGAN BANTUAN MEDIA VIDEO UNTUK MENINGKATKAN KETERAMPILAN MENULIS TEKS EKSPLANASI SISWA KELAS XI IIS SMA NEGERI 1 SINGARAJA. Journal of education action research, 2(2), 123-133.

Winata, N. P. S., Putrayasa, I. B., \& Sudiara, I. N. S. (2014). Analisis Butir Soal Pilihan Ganda Mata Pelajaran Bahasa Indonesia SMK Negeri 3 Singaraja. Jurnal Pendidikan Bahasa Dan Sastra Indonesia Undiksha, 2(1).

Utami, S. A., \& Nurgiyantoro, B. (2016). KUALITAS SOAL DAN DAYA SERAP TES PENDALAMAN MATERI UN BAHASA INDONESIA SMP DI GUNUNGKIDUL. Diksi, 24(1).

Yudiona, V. (2014). Menulis Tes Hasil Belajar. Jakarta: Grma Press. 